\title{
Universiteit
}

Leiden

The Netherlands

\section{Een postkoloniaal oogje dichtknijpen}

Veer, C.B. van 't

\section{Citation}

Veer, C. B. van 't. (2021). Een postkoloniaal oogje dichtknijpen. Tijdschrift Voor Nederlandse Taal- En Letterkunde, 137(2), 168-170.

doi:10.5117/TNTL2021.2.005.VEER

Version:

Publisher's Version

License:

Licensed under Article 25fa Copyright Act/Law (Amendment Taverne)

Downloaded from: $\quad$ https://hdl.handle.net/1887/3217330

Note: To cite this publication please use the final published version (if applicable). 


\title{
Een postkoloniaal oogje dichtknijpen
}

\author{
Coen van 't Veer \\ Universiteit Leiden \\ c.b.van.t.veer@hum.leidenuniv.nl
}

Michiel van Kempen (red.), Het andere postkoloniale oog. Onbekende kanten van de Nederlandse (post)koloniale cultuur en literatuur. Hilversum: Uitgeverij Verloren, 2020. 320 pp. ISBN: 9789087048655 . $3_{32,-}$

Op 1 september 2006 werd Michiel van Kempen bijzonder hoogleraar Nederlands-Caraïbische Letteren aan de Universiteit van Amsterdam. In 2019 bestond de leerstoel twaalf en een half jaar. Ter gelegenheid hiervan werd een letterkundig colloquium over de voormalige Nederlandse koloniën georganiseerd met als titel 'Verrassing!' De sprekers werden nogal vrij gelaten in hun onderwerpskeuze en -benadering: hun lezing moest een duidelijk raakvlak met de voormalige koloniën van Nederland hebben en over een verrassende, lastig te plaatsen letterkundige of cultuurwetenschappelijke ontdekking gaan.

Eind 2020 verscheen een boek waarvan de titel alleen al hoge verwachtingen opriep: Het andere postkoloniale oog. Onbekende kanten van de Nederlandse (post)koloniale cultuur en literatuur, onder redactie van Michiel van Kempen. Daarin zijn de meeste lezingen van het colloquium terechtgekomen. Van Kempen doet in zijn korte inleiding een poging om de 'verrassingen' van 2019 onder een postkoloniale parasol samen te brengen, maar halverwege zijn verhaal geeft hij aan dat het hier vooral een bundel met 'bijvangst' betreft: een verzameling van letterkundige of cultuurwetenschappelijke vondsten die door de auteurs van de bijdragen ooit terzijde waren geschoven.

'(Post)koloniale bijvangst' was dan ook een betere titel voor de bundel geweest. Achteraf gezien is Het andere postkoloniale oog geen gelukkige keus als titel voor dit boek, want Van Kempen worstelt in zijn voorwoord met wat nu precies onder het begrip 'postkoloniaal' moet worden verstaan. Hij noemt veelzijdigheid, het kritisch bevragen van het analytisch instrumentarium van de wetenschapper en veegt vervolgens een aantal begrippen uit de postkoloniale literatuur- en cultuurwetenschap op een hoop. Maar wat kijken 
met het andere postkoloniale oog is of zou moeten opleveren, wordt nergens duidelijk gemaakt. Uit de bundel blijkt dat voor Van Kempen postkoloniaal alles kan zijn, zolang er maar een band is met het koloniale verleden (van Nederland). Dit ontbreken van een helder afgebakend uitgangspunt is goed te zien in de bundel. De meeste auteurs blijken in hun bijdragen het postkolonialisme te beschouwen als de periode na het kolonialisme, slechts een enkeling hanteert een benadering die tegenwoordig gangbaar is in postcolonial studies.

Zo bestaat de eerste bijdrage uit de feestrede voor Van Kempen die J.Z. Herrenberg aan het einde van het colloquium in 2019 uitsprak. Aan het begin van zijn feestelijke toespraak feliciteert Herrenberg de jubilaris in één regel en gaat vervolgens over tot een bespreking van het leven en werk van Herrenberg zelf. Ook sommige andere stukken zijn wel erg persoonlijk en de woorden 'ik' en 'mij' komen er zo vaak in voor, dat de lezer zich geregeld afvraagt of het niet beter was geweest om wat meer academische distantie tot het onderwerp in acht te nemen.

In Het andere postkoloniale oog staan bovendien heel wat stukken van wetenschappers die met oude onderwerpen aan komen zetten, waarover ze niets nieuws of verrassends hebben te melden. In sommige gevallen is er zelfs een reeds gepubliceerde tekst integraal overgenomen, zoals de Verweylezing van Karin Amatmoekrim uit 2019. De lezer die haar - overigens prachtige - stuk in de ochtend of de middag tot zich neemt, kijkt toch een beetje vreemd op als deze leest: 'Vanavond wil ik echter samen met $u$ het verlies kantelen...' (p. 243).

Ook in de wetenschappelijke verantwoording is het boek allesbehalve een eenheid. De bijdragen hadden strakker geredigeerd moeten worden, zo blijkt ook uit het gebrek aan uniformiteit in annotaties en bronvermeldingen. Voetnoten, noten in de lopende tekst, bibliografieën, bibliografische aantekeningen, bronvermeldingen, bronnen, verantwoordingen, 'literatuur' - alles mag.

Voor wie een (postkoloniaal) oogje dichtknijpt, valt er echter genoeg te genieten. Naast goedgeschreven stukken van auteurs als Jacqueline Bel, Kees Snoek en Remco Raben, staan er sterke staaltjes van gedegen historisch onderzoek in de bundel. Zo mogen de artikelen van Hilde Neus over het blijspel Hans Michel en van Gábor Pusztai over de gefantaseerde koloniale avonturen van de Hongaar András Jelky niet onvermeld blijven. De vertaling van een oorspronkelijke tekst over Jelky is boeiend om te lezen. Klaas de Groot verdient een compliment voor het opnemen van enkele ongepubliceerde Indische gedichten van de in Paramaribo geboren Bernardo Ashetu. 
De artikelen waarin écht geprobeerd wordt om met een ander postkoloniaal oog naar literatuur te kijken, laten zien dat zo'n benadering ook daadwerkelijk verrassende inzichten kan opleveren. De bijdrage van Judit Gera over het herschrijven van het verhaal Mijn aap schreit van Albert Helman door Abdelkader Benali, het stuk van Margriet van der Waal over Buys: 'n Grensroman en de 'post-humanistische' analyse van Yra van Dijk van Astrid Roemers Lijken op liefde bieden de lezer een nieuw perspectief. Ook de bespreking van het werk van de nieuwe generatie Nederlands-Caraïbische auteurs door Michiel van Kempen zelf is een mooi stuk. Helaas betreft het ook hier geen nieuw artikel. Het is een bewerkte versie van een artikel dat eerder in Ons Erfdeel is verschenen.

De collectie opstellen, 'een reeks verkenningen met een groothoeklens', fungeert slechts zelden als de 'spiegel waarin de beschouwer zichzelf moet herdefiniëren' (p. 12), zoals Van Kempen in de inleiding aankondigt. Wie zich echter niet blind staart op de titel van het boek en bereid is om met een open blik naar de bijdragen in de bundel te kijken, kan met Een ander postkoloniaal oog beslist enkele mooie momenten beleven. 